\title{
Effect of impurity on thermally self-sustained double reactor coupling hydrogen production from glycerol reforming and methanol production from carbon dioxide and hydrogen
}

\author{
Sasinun Thirabunjongcharoen ${ }^{1}$, and Pattaraporn Kim-Lohsoontorn ${ }^{1, *}$ \\ ${ }^{1}$ Centre of Excellence on Catalysis and Catalytic Reaction Engineering, Department of Chemical \\ Engineering, Faculty of Engineering, Chulalongkorn University, Bangkok, 10330, Thailand
}

\begin{abstract}
Thermally self-sustained double reactor (TSSDR) operating without external heat source consists of dual channels for endothermic and exothermic reactions. Hydrogen $\left(\mathrm{H}_{2}\right)$ is produced from wasted glycerol by aqueous-phase glycerol reforming (APGR) at 200-250 ${ }^{\circ} \mathrm{C}$ and 20-25 bar while carbon dioxide $\left(\mathrm{CO}_{2}\right)$ is a by-product. Produced $\mathrm{H}_{2}$ and $\mathrm{CO}_{2}$ are used as raw materials for methanol synthesis (MS) at $200-250{ }^{\circ} \mathrm{C}$ and $50-80$ bar. Methanol synthesis and glycerol reforming occur at inner and outer channels of TSSDR, respectively. The TSSDR is fully packed with catalyst. Generated heat of exothermic reaction is sufficient for endothermic reaction. Main products of glycerol reforming in gas phase are $\mathrm{H}_{2}$ and $\mathrm{CO}_{2}$ while $\mathrm{CO}$ and $\mathrm{CH}_{4}$ are by-products. All products in gas phase are totally recycled as a feed stream for exothermic channel. $\mathrm{CO}$ and $\mathrm{CH}_{4}$ in feed reduce $\mathrm{CO}_{2}$ conversion and methanol yield in MS. The effect of impurities in glycerol feed stream also influences with hydrogen production in APGR. Especially, methanol, which is an impurity in glycerol feed obtained from biodiesel production, significantly reduces glycerol conversion in TSSDR.
\end{abstract}

\section{Introduction}

Methanol is an essential chemical and primary feedstock for paraffins, olefins and various organic compounds such as acetic anhydride, acetic acid and formaldehyde [1]. MS is generally carried out in gas phase at high pressure and temperature of 50-80 bar and 200-300 ${ }^{\circ} \mathrm{C}$ with $\mathrm{Cu} / \mathrm{ZnO} / \mathrm{Al}_{2} \mathrm{O}_{3}$ as a catalyst. As this reaction is exothermic, researchers have devised schemes to use heat released from MS in other reactions. Rahmanifard et al. [2] studied MS in thermally coupled membrane where MS is a heat source for cyclohexane dehydrogenation and Nimcar et al. [3] utilized the exothermic heat from MS in benzene production. Generally, methanol is produced from reformed natural gas (syngas), resulting in $\mathrm{CO}_{2}$ emission which has negative impact to environment. Methanol can be produced from $\mathrm{CO}_{2}$ conversion which can be a promising method to reduce $\mathrm{CO}_{2}$ emission while producing higher value products. However, hydrogen $\left(\mathrm{H}_{2}\right)$ source and availability are still a major barrier for $\mathrm{CO}_{2}$ conversion.

* Corresponding author: pattaraporn.k@,chula.ac.th 
Glycerol is waste from biodiesel production and can be available source for $\mathrm{H}_{2}$ production. Normally, glycerol reforming is endothermic reaction is generated in gas phase at high temperature $\left(400-700{ }^{\circ} \mathrm{C}\right)$ [4]. Glycerol reforming can be carried out at different operating condition-autothermal glycerol reforming, photo-reforming and aqueous phase glycerol reforming (APGR). The features of APGR are that no vaporization of the feedstock is required, which could decrease the input energy compared to steam reforming. This reaction can operate at low temperature $\left(200-250{ }^{\circ} \mathrm{C}\right)[5,6]$. Commercial catalysts for APGR is noble metal on alumina or carbon. $\mathrm{Pt} / \mathrm{Al}_{2} \mathrm{O}_{3}$ can be used as a catalyst and was reported to provide glycerol conversion around 50-60 \% [7] with a feed glycerol to water ratio of 1:9. However, production of $\mathrm{H}_{2}$ from glycerol produces $\mathrm{CO}_{2}$ as by-product. Direct utilization of $\mathrm{CO}_{2}$ with $\mathrm{H}_{2}$ obtained from APGR can be another promising pathway for glycerol conversion with mitigating $\mathrm{CO}_{2}$ emission. APGR's products in gas phase consist of $\mathrm{H}_{2}, \mathrm{CO}_{2}, \mathrm{CH}_{4}$ and $\mathrm{CO}$ [8]. Methanation and reverse water gas shift reaction (RWGS) is likely occurred in MS at low temperature [9].

In this study, a novel thermally self-sustained double reactor (TSSDR) coupling endothermic APGR with exothermic MS is proposed. Heat transfer between the two reactions is enabled in this reactor and lead to more favourable conditions for higher reactant conversion. $\mathrm{H}_{2}$ and $\mathrm{CO}_{2}$ produced from APGR can be totally utilized in MS for methanol production. A computational fluid dynamic (CFD) model was established to study this TSSDR. Effects of impurities in APGR and MS were investigated.

\section{Model description}

The TSSDR in our study consists of two concentric channels: 1) an inner tube and 2) an outer annular channel. Fig. 1 shows a schematic diagram of this TSSDR. The diameter of the inner channel is $16 \mathrm{~mm}$ and the thickness of the annulus channel is $8 \mathrm{~mm}$. The wall between the two channels is $2 \mathrm{~mm}$ thick. The reactor height is $150 \mathrm{~mm}$. The inner channel is intended for MS and the outer channel is designed for APGR. $\mathrm{Cu} / \mathrm{ZnO} / \mathrm{Al}_{2} \mathrm{O}_{3}$ catalyst for MS is packed in the inner channel, through which $\mathrm{CO}_{2}$ and $\mathrm{H}_{2}$ are supplied. A Pt/ $\mathrm{Al}_{2} \mathrm{O}_{3}$ catalyst for APGR is packed in the outer channel. Generated heat from the exothermic reaction in the MS channel is expected to transfer to the endothermic APGR channel. Both feed streams are fed vertically from the bottom to the top of the reactor as a base case configuration. 


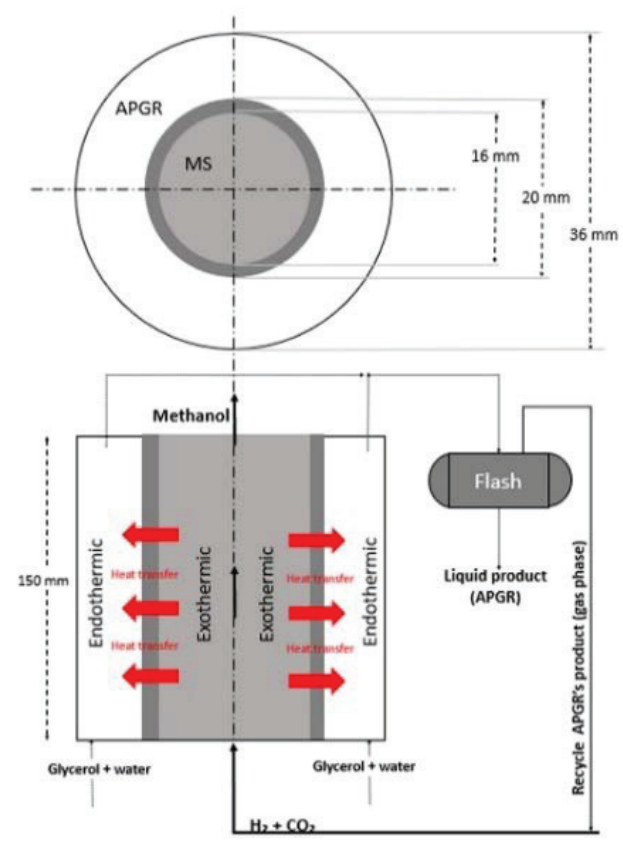

Fig. 1. TSSDR schematic design

\subsection{Kinetic rate}

\subsubsection{Methanol synthesis (MS)}

To calculate TSSDR model, methanol is synthesized by $\mathrm{CO}_{2}$ hydrogenation. Busshe et al. [10] explains the kinetic rate of $\mathrm{MS}$ with $\mathrm{Cu} / \mathrm{ZnO} / \mathrm{Al}_{2} \mathrm{O}_{3}$ at $200-250{ }^{\circ} \mathrm{C}$. In methanol production, $\mathrm{CH}_{4}$ and $\mathrm{CO}$ are undesired products in process. Possible reactions in MS are shown in Table 1.

Table 1. Possible reactions and kinetic rates in MS [10,11]

\begin{tabular}{|c|c|}
\hline Possible reaction & Rate expression \\
\hline $\begin{array}{l}\mathrm{CO}_{2} \text { hydrogenation: } \\
\mathrm{CO}_{2}+3 \mathrm{H}_{2} \leftrightarrow \mathrm{CH}_{3} \mathrm{OH}+2 \mathrm{H}_{2} \mathrm{O}\end{array}$ & $R_{M S}=\frac{\left(k_{1} P_{\mathrm{H}_{2}} P_{\mathrm{H}_{2} \mathrm{O}}\right)-\left(k_{6} P_{\mathrm{CO}_{2}} P_{\mathrm{CO}} / P_{\mathrm{H}_{2} \mathrm{O}}^{2}\right)}{\left(1+\left(k_{2} P_{\mathrm{CO}_{2}} P_{\mathrm{H}_{2} \mathrm{O}}\right)+\left(k_{3} P_{\mathrm{H}_{2} \mathrm{O}}^{0.5}\right)+\left(k_{4} P_{\mathrm{CO}_{2}}\right)\right)^{3}}$ \\
\hline $\begin{array}{l}\text { CO hydrogenation: } \\
\mathrm{CO}+2 \mathrm{H}_{2} \leftrightarrow \mathrm{CH}_{3} \mathrm{OH}\end{array}$ & $R_{M S, 2}=k_{1,0}\left(P_{C O} P_{\mathrm{H}_{2}}^{2}-\frac{P_{\mathrm{CH}_{3} \mathrm{OH}}}{K_{1}}\right)$ \\
\hline $\begin{array}{l}\text { Methanol dehydration: } \\
2 \mathrm{CH}_{3} \mathrm{OH} \leftrightarrow \mathrm{CH}_{3} \mathrm{OCH}_{3}+\mathrm{H}_{2} \mathrm{O}\end{array}$ & $R_{D M E}=k_{2,0}\left(P_{C H_{3} \mathrm{OH}}^{2}-\frac{P_{\mathrm{CH}_{3} \mathrm{OH}} P_{\mathrm{H}_{2} \mathrm{O}}}{K_{2}}\right)$ \\
\hline $\begin{array}{l}\text { Reverse water gas shift (RWGR): } \\
\mathrm{CO}_{2}+\mathrm{H}_{2} \leftrightarrow \mathrm{CO}+\mathrm{H}_{2} \mathrm{O}\end{array}$ & $R_{R W G S}=\frac{\left(k_{5} P_{\mathrm{H}_{2}}\right)-\left(k_{7} P_{\mathrm{CO}_{2}} P_{\mathrm{CH}_{3} \mathrm{OH}} / P_{\mathrm{H}_{2} \mathrm{O}}\right)}{\left(1+\left(k_{2} P_{\mathrm{CO}_{2}} P_{\mathrm{H}_{2} \mathrm{O}}\right)+\left(k_{3} P_{\mathrm{H}_{2} \mathrm{O}}^{0.5}\right)+\left(k_{4} P_{\mathrm{CO}_{2}}\right)\right)}$ \\
\hline $\begin{array}{l}\text { Methanation: } \\
\mathrm{CO}+3 \mathrm{H}_{2} \leftrightarrow \mathrm{CH}_{4}+\mathrm{H}_{2} \mathrm{O}\end{array}$ & $R_{\text {methane }}=k_{3,0}\left(P_{C O} P_{\mathrm{H}_{2}}^{3}-\frac{P_{\mathrm{CH}_{4}} P_{\mathrm{H}_{2} \mathrm{O}}}{K_{3}}\right)$ \\
\hline
\end{tabular}




\subsubsection{Aqueous-phase glycerol reforming (APGR)}

Glycerol and water were feedstock of APGR for hydrogen production with $\mathrm{CO}_{2}$ as a byproduct. Iliuta et al. [12] formulated a kinetic model of APGR with a $\mathrm{Pt} / \mathrm{Al}_{2} \mathrm{O}_{3}$ catalyst in a trickle bed reactor. Arely et al. [8] investigated the APGR in a batch slurry reactor. Methane, ethane and propane were detected as gaseous by-products while ethylene glycol and alcohols were detected as liquid products. The rate for side reactions in APGR are show in Table 2 when $\mathrm{k}_{\mathrm{i}, 0}$ is calculated by Arrhenius's equation.

Table 2. Possible reactions and kinetic rates in APGR [8, 9]

\begin{tabular}{|c|c|}
\hline Possible reaction & Rate expression \\
\hline $\mathrm{C}_{3} \mathrm{H}_{8} \mathrm{O}_{3}+3 \mathrm{H}_{2} \mathrm{O} \rightarrow 3 \mathrm{CO}_{2}+7 \mathrm{H}_{2}$ & $R_{A P G R, 1}=2.678 \exp \left(-\frac{60000}{R T}\right) C_{C_{3} H_{8} O_{3}}$ \\
\hline $\mathrm{C}_{3} \mathrm{H}_{8} \mathrm{O}_{3} \rightarrow 3 \mathrm{CO}+4 \mathrm{H}_{2}$ & $R_{A P G R, 2}=k_{2,0} \exp \left(\frac{-83990}{R T}\right) C_{C_{3} H_{8} O_{3}}$ \\
\hline $\mathrm{CH}_{3} \mathrm{OH}+\mathrm{H}_{2} \rightarrow \mathrm{CH}_{4}+\mathrm{H}_{2} \mathrm{O}$ & $R_{A P G R, 3}=k_{3,0} \exp \left(\frac{-84510}{R T}\right) C_{C H_{3} O H} \frac{C_{H_{2, g}}}{H_{H_{2}}}$ \\
\hline $\mathrm{CO}+\mathrm{H}_{2} \mathrm{O} \rightarrow \mathrm{CO}_{2}+\mathrm{H}_{2}$ & $R_{A P G R, 4}=k_{4,0} \exp \left(\frac{-130300}{R T}\right) \frac{C_{C O_{g}}}{H_{C O}}$ \\
\hline $\mathrm{CO}+3 \mathrm{H}_{2} \rightarrow \mathrm{CH}_{4}+\mathrm{H}_{2} \mathrm{O}$ & $R_{A P G R, 5}=k_{5,0} \exp \left(\frac{-133260}{R T}\right) \frac{C_{H_{2, g}}^{1.5}}{H_{H_{2}}}$ \\
\hline $\mathrm{CH}_{3} \mathrm{OH} \rightarrow \mathrm{CO}+3 \mathrm{H}_{2}$ & $=\left(1.17 \times 10^{-7} \exp \left(\frac{-40999}{R T}\right)\right) C_{\mathrm{CH}_{3} \mathrm{OH}}$ \\
\hline $3 \mathrm{CO}_{2}+4 \mathrm{H}_{2} \rightarrow \mathrm{CH}_{4}+2 \mathrm{H}_{2} \mathrm{O}$ & $\begin{array}{l}\left.R_{A P G R, 6}=\frac{1+\left(5.48 \times 10^{-5}\right) C_{C_{3} \mathrm{OH}}}{R T}\right) C_{C O_{2}}^{0.66} C_{H_{2}}^{0.21} \\
R_{A P G R, 7}=\left(1.75 \times 10^{-7}\right) \exp \left(\frac{-95000}{R T}\right.\end{array}$ \\
\hline
\end{tabular}

\subsection{Simulation method}

MS and APGR in TSSDR were simulated with COMSOL Multiphysics 5.3a. Steady-state flows of the feed gas mixtures was solved by mass, momentum, and energy balance equations of a discretized flow domain of the reactor geometry. The dual reactions were simulated in a 2D-axis-symmetric system in cylindrical coordinate. The flow regime in each channel was assumed to be steady and laminar. The diffusion of materials and the heat conduction in direction flow axis was neglected. The ideal gas and Peng-Robinson model was employed. The physical properties of the chemicals were initially defined with Perry's Chemical Engineers' Handbook [13]. The mathematical equations for the CFD model were divided into three parts. For Part I, MS was calculated at the surface of the solid catalyst. A constant bed void fraction was maintained for the entire length of the reactor. For Part II, APGR was calculated with three phases (gas-phase products, liquid-phase reactants and solid catalyst). For Part III, heat transfer through the solid wall was determined. Numerical solutions were obtained with the finite element method in COMSOL Multiphysics version 5.3a. The mesh resolution was free triangular with a mesh area of $0.0012 \mathrm{~m}^{2}$ and the number of elements of 1416. Performance of both reactions are measured by conversion, yield and selectivity, show in Eq. (1-6).

$$
\begin{aligned}
& \mathrm{CO}_{2} \text { conversion }=\frac{\text { mol of } \mathrm{CO}_{2} \text { inlet }- \text { mol of } \mathrm{CO}_{2} \text { outlet }}{{\text { mol of } \mathrm{CO}_{2} \text { inlet }}_{\text {inlel }}} \times 100 \\
& \mathrm{C}_{3} \mathrm{H}_{8} \mathrm{O}_{3} \text { conversion }=\frac{\text { mol of } \mathrm{C}_{3} \mathrm{H}_{8} \mathrm{O}_{3} \text { inlet }- \text { mol of } \mathrm{C}_{3} \mathrm{H}_{8} \mathrm{O}_{3} \text { outlet }}{\text { mol of } \mathrm{C}_{3} \mathrm{H}_{8} \mathrm{O}_{3} \text { inlet }} \times 100
\end{aligned}
$$




$$
\begin{aligned}
& \% \text { yield of } \mathrm{H}_{2}=\frac{\text { mol of } \mathrm{H}_{2} \text { generated }}{\text { mol of } \mathrm{C}_{3} \mathrm{H}_{8} \mathrm{O}_{3} \text { feed }} \times 100 \\
& \% \text { yield of } \mathrm{CH}_{3} \mathrm{OH}=\frac{\text { mol of } \mathrm{CH}_{3} \mathrm{OH} \text { generated }}{\text { mol of } \mathrm{CO}_{2} \text { feed }} \times 100 \\
& \% \text { selectivity of } \mathrm{APGR} \text { product }=\frac{\text { mol of desired product }}{\text { mol of } \mathrm{C}_{3} \mathrm{H}_{8} \mathrm{O}_{3} \text { reacted }} \times 100 \\
& \% \text { selectivity of } \mathrm{MS} \text { product }=\frac{\text { mol of desired product }}{\text { mol of } \mathrm{CO}_{2} \text { reacted }} \times 100
\end{aligned}
$$

\section{Result \& Discussion}

Simulation for the model validation was performed for the MS and APGR channels separately in adiabatic model. The MS model accuracy was assured at an average error of only $0.88 \%$ based on average of all components when compared with Busshe et al [10]. In APGR, the average error is $2.82 \%$ when comparing output composition with Iliuta et al. [12]. This research divides TSSDR model into three cases. Case I is the base case condition: MS inlet temperature of $220^{\circ} \mathrm{C}$; MS inlet pressure of 50 bar; MS total flow rate of $0.003 \mathrm{~mol} \mathrm{~s}^{-1}$; MS external feed $\mathrm{H}_{2}$ to $\mathrm{CO}_{2}$ ratio of 82:3; APGR inlet temperature of $220^{\circ} \mathrm{C}$; APGR inlet pressure of 20 bar; MS total flow rate of $0.0005 \mathrm{~mol} \mathrm{~s}^{-1}$; APGR external feed glycerol to water ratio of 1:9. Case II is the TSSDR model without external feed of $\mathrm{H}_{2}$ and $\mathrm{CO}_{2}$ in MS feed stream. MS feed totally relied on APGR's gas products. Case III is the TSSDR model was similar to case II plus methanol as impurity in APGR feed side.

As presented in Fig 2, methanol yield and $\mathrm{CO}_{2}$ conversion in base case were higher than other conditions since $\mathrm{H}_{2}$ was highly excess. $\mathrm{CO}_{2}$ hydrogenation is based on theoretical ratio of $\mathrm{H}_{2}$ to $\mathrm{CO}_{2}$ at 3 . There was a reaction between hydrogen and $\mathrm{CO}$ ( $\mathrm{CO}$ hydrogenation). Therefore, methanol yields in base case was higher than $\mathrm{CO}_{2}$ conversion. On the other hand, total recycle of APGR's gas product to MS influenced $\mathrm{CO}_{2}$ conversion decreased to $36.36 \%$ because the ration of $\mathrm{H}_{2}$ to $\mathrm{CO}_{2}$ in feed was decreased to 3:1. Gas products in APGR consisted of the main product $\left(\mathrm{H}_{2}, \mathrm{CO}_{2}\right)$ and undesired products $\left(\mathrm{CO}, \mathrm{CH}_{4}\right.$ and methanol) which led to a reduction in methanol production.

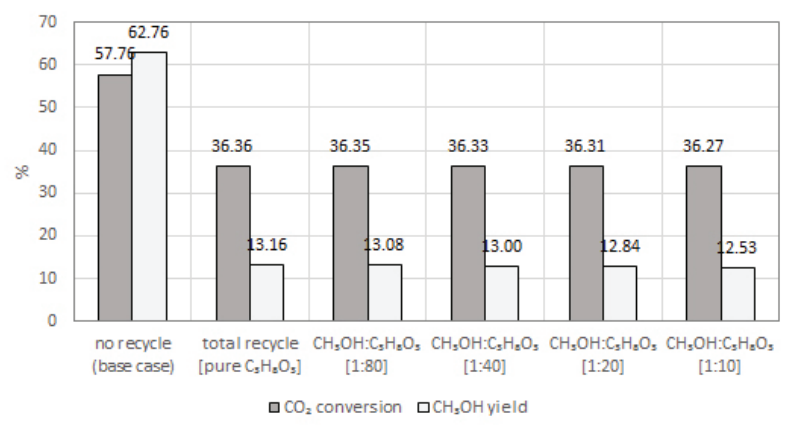

Fig. 2. Comparing $\mathrm{CO}_{2}$ conversion and $\mathrm{CH}_{3} \mathrm{OH}$ yield in exothermic side: (1) TSSDR with external feed $\mathrm{H}_{2}$ and $\mathrm{CO}_{2}$, (2) TSSDR with total recycle APGR's gas product, (3) Effect of methanol impurity in APGR's feed stream (ratio = 1:80), (4) Effect of methanol composition in APGR's feed stream $($ ratio $=1: 40),(5)$ Effect of methanol composition in APGR's feed stream (ratio = 1:20), (6) Effect of methanol composition in APGR's feed stream (ratio $=1: 10)$. 
As presented in Fig. 3, there were a minor change in $\mathrm{H}_{2}$ yield and glycerol conversion in all cases because the molar of pure glycerol in water solution was constant although methanol was introduced as impurity in feed.

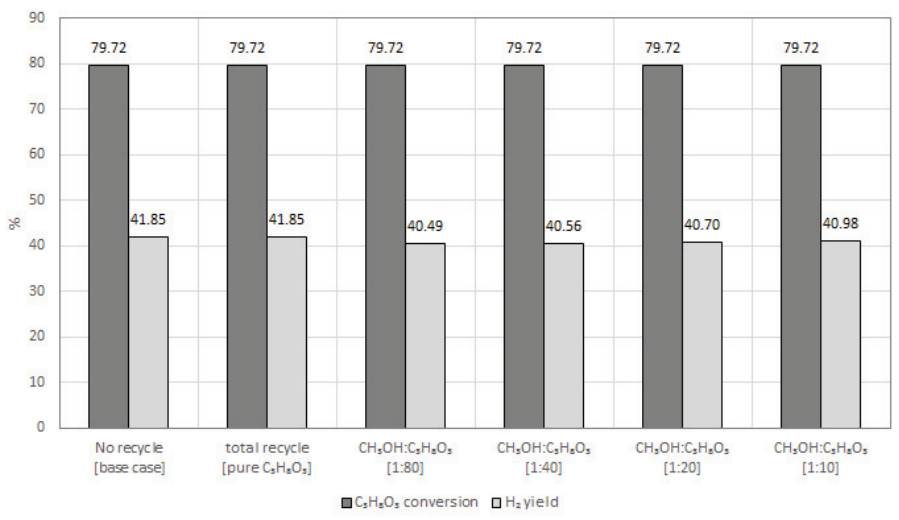

Fig. 3. Comparing $\mathrm{C}_{3} \mathrm{H}_{8} \mathrm{O}_{3}$ conversion and $\mathrm{H}_{2}$ yield in endothermic side: (1) TSSDR with external feed $\mathrm{H}_{2}$ and $\mathrm{CO}_{2}$, (2) TSSDR with total recycle APGR's gas product, (3) Effect of methanol composition in APGR's feed stream (ratio =1:80), (4) Effect of methanol composition in APGR's feed stream (ratio $=1: 40$ ), (5) Effect of methanol composition in APGR's feed stream (ratio = 1:20), (6) Effect of methanol composition in APGR's feed stream (ratio = 1:10).

In reality, crude glycerol which is obtained from biodiesel production could contain methanol as impurity. Fig. 4 shows the effect of methanol in glycerol feed in APGR on product selectivity in MS. Selectivity of MS's product insignificantly decreased. There was a separation of liquid product by condensation before recycling to MS. Methanol was removed before entering MS.

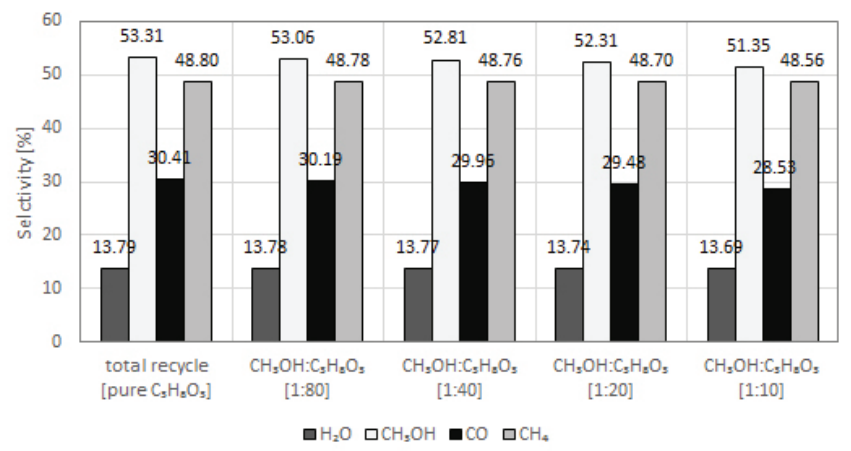

Fig. 4. Selectivity of MS's product base on $\mathrm{CO}_{2}$ reacted: (1) TSSDR with external feed $\mathrm{H}_{2}$ and $\mathrm{CO}_{2}$, (2) TSSDR with total recycle APGR's gas product, (3) Effect of methanol composition in APGR's feed stream (ratio = 1:80), (4) Effect of methanol composition in APGR's feed stream (ratio = 1:40), (5) Effect of methanol composition in APGR's feed stream (ratio = 1:20), (6) Effect of methanol composition in APGR's feed stream (ratio = 1:10). 
Fig. 5 presents effect of methanol impurity in APGR feed on the selectivity of APGR products. Methanol selectivity dropped to the negative value. Generated methanol is less than molar feed of methanol. Methanol could decompose to $\mathrm{H}_{2}$ and $\mathrm{CO}$ and generated $\mathrm{CH}_{4}$ following the reaction presented in Table 2. Methanol in glycerol solution decreased when the ratio of impurity increased.

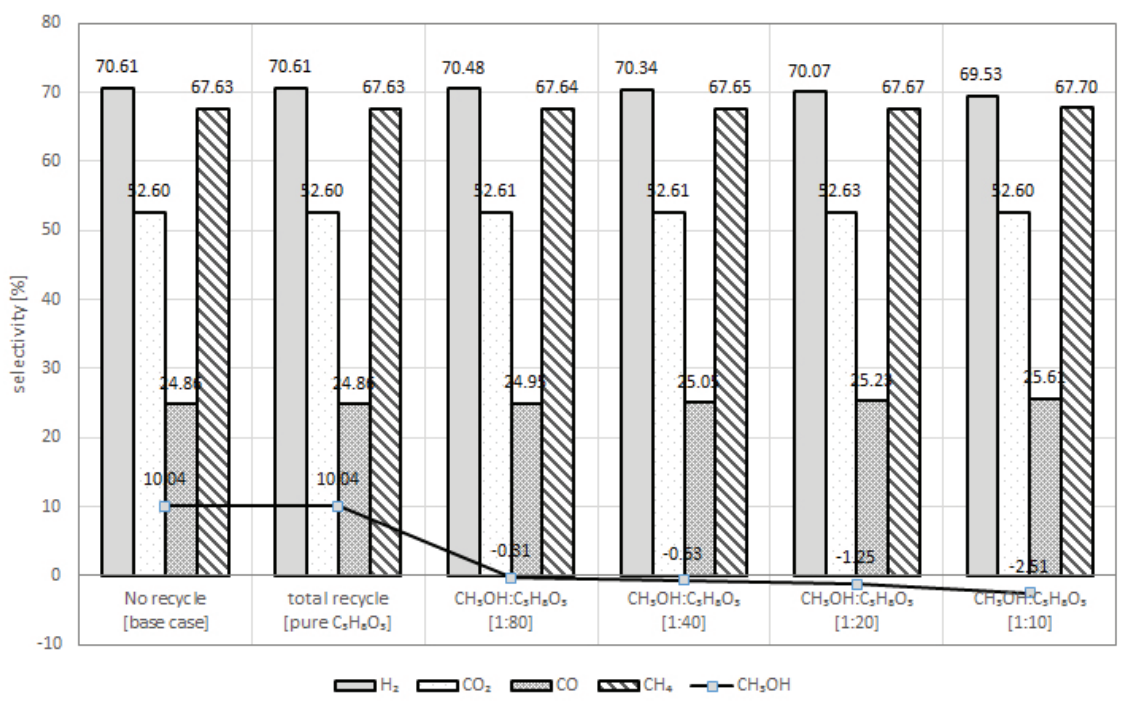

Fig. 5. Selectivity of APGR's product base on theoretical $\mathrm{C}_{3} \mathrm{H}_{8} \mathrm{O}_{3}$ reacted: (1) TSSDR with external feed $\mathrm{H}_{2}$ and $\mathrm{CO}_{2}$, (2) TSSDR with total recycle APGR's gas product, (3) Effect of methanol composition in APGR's feed stream (ratio = 1:80), (4) Effect of methanol composition in APGR's feed stream (ratio = 1:40), (5) Effect of methanol composition in APGR's feed stream (ratio = 1:20), (6) Effect of methanol composition in APGR's feed stream (ratio = 1:10).

\section{Conclusion}

Thermally self-sustained double reactor (TSSDR) consisted of dual channels for APGR and MS. TSSDR could operate without external heat and external feed supplied in MS. $\mathrm{H}_{2}$ and $\mathrm{CO}_{2}$ was produced APGR and was recycled to produce methanol in MS. Therefore, byproducts in APGR affected methanol production in MS. The effect of methanol in glycerol feed stream influenced hydrogen production in APGR. Therefore, feed compositions in MS and APGR were important variables and significantly affected the reactor's performance.

Acknowledgment is made to Thailand Graduate Institute of Science and Technology (TGIST) fund from National Science and Technology Development Agency (NSTDA) and CAT-REACT Industrial Project from Thailand Science and Research Innovation (TSRI). P. Kim-Lohsoontorn would like to acknowledge Research Cess Fund, Malaysia-Thailand Joint Authority (MTJA), Thailand Science Research and Innovation (TSRI) and NSTDA Chair Professor Grant from NSTDA.

\section{References}

1. A.C.C. de Souza, J.L. Silveira, Renewable and Sustainable Energy Reviews, 15, 1835-50, (2011).

2. H. Rahmanifard, R. Vakili, T. Plaksina, Mohammad Reza Rahimpour, X.F. Masoud Babaei, Computers \& Chemical Engineering, 119, 258-69, (2018). 
3. S.C. Nimkar, R.K. Mewada, M.A. Rosen, International Journal of Hydrogen Energy, 42, 2811327, (2017).

4. C.A. Schwengber, H.J. Alves, R.A. Schaffner, F.A.d. Silva, R. Sequinel, V.R. Bach, R.J. Ferracin, 58, 259-6, (2016).

5. D.A. Boga, F. Liu, P.C.A. Bruijnincx, B.M. Weckhuysen, Catalysis Science \& Technology, 6, 134-43, (2016).

6. P.V. Tuza, R.L. Manfro, N.F.P. Ribeiro, M.M.V.M. Souza, Renewable Energy, 50, 408-14, (2013).

7. V. Domínguez-Barroso, Fuel processing technology, v. 190, pp. 21-8-2019 v.190, (2019).

8. A. Torres, D. Roy, B. Subramaniam, R.V. Chaudhari, Ind Eng Chem Res, 49, 10826-35, (2010).

9. I. Coronado, A. Arandia, M. Reinikainen, R. Karinen, R.L. Puurunen, J. Lehtonen, Catalysts, 9 , (2019).

10. V.B. KM, F. Gilbert, Journal of Catalysis, 161, 1-10, (1996).

11. A.T. Aguayo, J. Ereña, D. Mier, J.M. Arandes, M. Olazar, J. Bilbao, Industrial \& Engineering Chemistry Research, 46, 5522-30, (2007).

12. I. Iliuta, M.C. Iliuta, P. Fongarland, F. Larachi, Chemical Engineering Journal, 187, 311-27, (2012).

13. R.H. Perry, D.W. Green, Perry's chemical engineers' handbook, (2008). 